\title{
Hedge Fund Leverage Before and after the Crisis
}

\author{
Barry Eichengreen \\ University of California, Berkeley \\ Bokyeong Park \\ Presidential Commission on Policy Planning, Korea
}

\begin{abstract}
We present new evidence on the use of leverage by hedge funds and on how this changed following Russia's default and the near failure of Long-Term Capital Management in the summer and fall of 1998. We use regression techniques and survey data to analyze how leverage varies with fund attributes. We show that leverage varies with investment style, regulatory status, and a variety of other fund characteristics. While the use of leverage fell across the board between 1998 and 1999, it appears that hedge funds whose investment styles, regulatory status and other attributes were associated with the greatest utilization of leverage before the crisis reduced their use of it most sharply thereafter.
\end{abstract}

- JEL Classification: Q1, F3

- Key Words: Hedge Funds, Financial Markets, Financial Crises

\section{Introduction}

Hedge funds are the most prominent members of the class of financial market participants referred to by officials and regulators as "highly-leveraged institutions." This label is indicative of one of the characteristics of these private

\footnotetext{
*Corresponding address: Department of Economics, University of California, Berkeley, California 94720-388 USA, Tel.: +510-6422772, Fax.: +510-6430926, E-mail: aichengr@econ.berkeley.edu ${ }^{1}$ In practice, a mutual funds debts are not allowed to exceed one-third of its assets, limiting on-balance sheet leverage. The Investment Company Act of 1940 limits the ability of mutual funds to engage in short sales and repurchase transactions, and the Securities and Exchange Commission (SEC) strictly monitors and controls their use of derivatives.

(c)2002-Center for International Economics, Sejong Institution, All Rights Reserved.
} 
investment pools that is of particular concern in the official community. Hedge funds, unlike mutual funds, are not governed by regulations limiting the ratio of borrowed to own funds that they can devote to investments. ${ }^{1}$ Some use substantial amounts of credit. They buy securities and derivative instruments on margin. In some cases, the famous one being Long-Term Capital Management (LTCM), they negotiate lines of credit with their banks.

That hedge funds are highly leveraged is at least part of the explanation for why their activities have attracted attention at the national and international levels. In emerging markets the fact that a handful of fund managers can access substantial amounts of credit creates concern about their ability to take large positions and precipitate movements in currencies and securities prices. In the United States and Europe the all-but-failure of LTCM, whose on-balance-sheet leverage ratio came to exceed 50 in August 1998, created concerns over what such use of leverage implies for systemic stability. ${ }^{2}$ The result has been a debate over the desirability of reforms to encourage prudence in the extension of credit to and the use of leverage by hedge funds. Proposals include strengthening incentives for counterparty risk management, mandating additional disclosure of hedge fund positions and credit to counterparties and the public, and imposing regulatory limits on the use of leverage through the application of capital, liquidity and licensing standards to hedge funds and/or margin requirements to their investments. ${ }^{3}$

Unfortunately, progress has been hampered by the very limited information available on the leverage used by such entities. This problem has three aspects. First, hedge funds are not required to disclose the leverage they use; disclosure is voluntary, and the meaning of the figures reported by fund managers, typically in response to industry surveys, is not always clear. ${ }^{4}$ Second, different funds are known to employ different amounts of leverage, rendering generalizations about this behavior problematic. Third, anecdotal evidence suggests that the use of credit by highly-leveraged institutions declined significantly in the wake of Russia-LTCM crisis, which suggested to fund managers, shareholders and counterparties that the

\footnotetext{
${ }^{2}$ Lowenstein (2000), p.159. U.S. President's Working Group on Financial Markets (1999) reports one hedge fund with on-balance sheet leverage above 30 in September 1998. Our inference that the fund in question is LTCM.

${ }^{3}$ See U.S. President's Working Group (1999), Basle Committee on Banking Supervision (1999, 2000), and Financial Stability Forum (2000).

${ }^{4}$ Among the commercial entities that survey the hedge fund industry are the Hennessee Group (whose data we use below), Hedge Fund Research (HFR), Managed Account Reports Inc. (MAR/Hedge), and Van Hedge Fund Advisors.
} 
risks of highly-leveraged investment strategies may have been underestimated. ${ }^{5}$

In this paper we present new evidence on the use of leverage by hedge funds, on its determinants, and on how this behavior has changed since the Russia-LTCM crisis. We use regression techniques to analyze the use of leverage by individual hedge funds and how its use varies with fund attributes. In addition, we have matching observations for the periods before and after the Russia-LTCM crisis. Along with enhancing our understanding of the use of leverage by the hedge fund industry in the past, these findings thus shed light on how changes in the size distribution of firms and the mix of investment styles may affect it in the future.

\section{Definitions}

Hedge funds, as private partnerships of high-income investors, are not subject to the provisions of the U.S. Investment Company Act of 1940. They are not required to incorporate under state law as corporations or business trusts and are not subject to federal legislative restrictions on their activities and organization. They are not required to register with the U.S. Securities and Exchange Commission. This means that there are no legislative or regulatory restrictions on their use of borrowed funds.

Discussions of hedge funds' use of credit typically focus on on-balance sheet leverage -- that is, on the ratio of assets (or the sum of assets and liabilities) to own capital. ${ }^{6}$ This is the measure of leverage reported by fund managers to their shareholders and the markets (when they report any measure at all). But leverage can also arise as a result of short positions, repurchase agreements, derivatives contracts, and other transactions that do not appear on the balance sheet. A fund may have engaged in a short sale, for example -- it may have borrowed a security and sold it, incurring the obligation to repurchase it at the time the contract to borrow it expires -- without having to put up collateral. (More typically, these exposures are collateralized at current market value, but when market value changes the borrower may be required to post additional collateral only with delay.) In the case where a fund has put up no collateral, a comprehensive measure of leverage (summing on- and off-balance sheet leverage) would add this

\footnotetext{
${ }^{5}$ In the words of Metzger (1999, p.3), "since the troubles of Long-Term Capital, many hedge funds, some voluntarily and others under pressure from their investors or lenders, have decreased their leverage, and refocused their trading on strategies that rely less on leverage."

${ }^{6} \mathrm{This}$ is referred to as on-balance sheet leverage because assets, capital and liabilities are all balance sheet items.
} 
additional liability to on-balance sheet liabilities. Similarly, a position in derivative securities may imply a liability several times the value of the initial margin that the trader taking that position must put up with the counterparty booking the deal without showing up on the balance sheet.

Many of these obligations are contingent liabilities -- that is, their value depends on the realization in the future of ex ante uncertain variables. In addition, there is the problem of netting offsetting positions, for example boxed positions (where a fund simultaneously goes long and short the same number of shares in a particular enterprise). Because such positions serve to reduce market risk, counting them when computing leverage can give a misleading impression of the associated risks. For all these reasons, accounting (balance-sheet-based) measures of leverage may fail to capture the relationship between the riskiness of the portfolio (including market risk, counterparty credit risk, and liquidity risk) and the capacity of the fund to absorb losses, what is often referred to as economic leverage. Measures of economic leverage (such as value-at-risk relative to net worth), even when they are estimated in house, are only rarely disclosed by hedge funds to their shareholders or the market. Evidence of its extent is therefore largely anecdotal. Thus, whereas LTCM is estimated to have had an on-balance sheet leverage ratio of perhaps 50 in September 1998, observers have conjectured, on the basis of conversations with market participants, that its economic leverage was much higher.

Eichengreen and Mathieson et al. (1998) report the opinions of market participants that the share of security portfolios that hedge funds were required to hold as collateral ("haircuts") at the end of 1997 varied from 50 per cent on equities to 1-2 per cent on U.S. treasury bonds, reflecting the counterparties perceptions of value at risk. They report that haircuts declined over the first half of the 1990s as hedge funds acquired a track record of solid performance and counterparties became more familiar with hedge-fund operations, allowing better-known funds to buy structured derivative products without putting up any initial collateral. Official studies that have revisited these practices subsequent to the Russia-LTCM crisis (viz. Financial Stability Forum 2000) report increases in haircuts.

Managed Account Reports Inc. (MAR/Hedge) data for the mid-1990s show that between 60 and 70 per cent of hedge funds acknowledged using leverage while 15 to 20 per cent reported that they did not (and the remainder did not report). Data gathered by Hedge Fund Research (HFR) suggest a modest increase in the proportion of funds using leverage over this period. ${ }^{7}$ Previous analyses of on-

\footnotetext{
${ }^{7}$ Data from both sources are reported in Chadha and Jansen (1998), p.36.
} 
balance sheet leverage show that this varies by investment style. Data gathered by Van Hedge Fund Advisors (reproduced in Yago, Ramesh and Hochman 1998, p.7) suggest that at the end of 1997 (that is, prior to the Russia-LTCM crisis) the share of hedge funds utilizing leverage was highest for macro-oriented funds (those taking positions in currency and bond markets on the basis of the implications for the returns on these assets of government policies), arbitrage funds (the category in which LTCM is conventionally placed), and special-situation funds (which are engaged in merger arbitrage, etc.). It was lowest among hedge funds investing in distressed securities, a notoriously risky strategy. ${ }^{8}$ While most hedge funds report using leverage, the vast majority employ a ratio of less than 2 to 1 (that is, less than a dollar of credit for each dollar of capital).

\section{Policy Issues}

The use of leverage by hedge funds was drawn to the attention of policy makers by volatility in the U.S. bond market in 1993-4, when distress sales by highly-leveraged macro funds were said to have amplified price volatility. Allegations to this effect prompted investigations by the Federal Reserve Bank of New York and the Bank of England and hearings by the Committee on Banking, Finance and Urban Affairs of the U.S. House of Representatives. Witnesses argued that macro funds with large long positions funded with margin were forced to deleverage when the Federal Reserve unexpectedly raised interest rates, causing bond prices to fall, and that this magnified the impact of Federal Reserve action on the economy. In addition, because these same hedge funds had long positions in European securities markets, they also sold off some of those holdings to meet margin calls, transmitting the fall in U.S. securities prices and rise in U.S. interest rates to European markets more powerfully than would otherwise have been the case (U.S. Congress, 1994).

With the recovery and growth of hedge-fund capitalization in 2000 and 2001, the possibility was raised again that hedge fund activities were altering the economy's response to monetary policy. Thus, Hale (2001) suggested that the tendency for hedge funds to trade more aggressively and to use more credit and leverage than other investors caused interest-rate cuts to translate into larger increases in equity prices and Tobins $\mathrm{q}$ than has historically been the case.

\footnotetext{
${ }^{8}$ The Hennessee Group data used here tell the same story, although they do not distinguish funds using no leverage from funds whose assets were less than 200 per cent of capital, making it harder to make equally firm statements. See Section 4 below.
} 
Concerns about the trade- and position-taking activities of hedge funds have also been expressed outside the United States. It was alleged in 1997-8 that hedge funds had been able to take substantial short positions in Asian markets as a result of the leverage provided by their counterparties. In Thailand in 1997 they were said to have taken short positions in the local foreign exchange market on the order of anywhere from $\$ 7$ billion (Eichengreen and Mathieson 1997) to $\$ 15$ billion (de Brouwer 2001). In 1998 they took large short positions in both the Hang Seng Stock Exchange (using futures, on which the margin requirement is 5 per cent, as well exchange-traded and over-the-counter derivatives like options, on which no such requirements exist) and in the Hong Kong dollar (using forward contracts). The Market Dynamics Study Group (MDSG) of the Financial Stability Forum (2000) reports data assembled by the Hong Kong regulatory authorities indicating that hedge fund positions accounted for at least 50 per cent of the short open positions on the Hang Seng in the summer of $1998 .{ }^{9}$ There followed complaints that hedge funds had cornered and manipulated the market in the Australian dollar (Rankin 1999) which were also picked up by the MDSG. Both episodes thus fueled complaints that hedge funds, using leverage, were manipulating and destabilizing conditions in emerging financial markets.

Worries about hedge fund leverage peaked with the collapse of Long-Term Capital Management late in the summer of 1998. LTCM had begun trading in 1994 as a relative value fund with a portfolio of U.S. treasury securities and related derivatives. The market in U.S. treasuries being relatively efficient, price discrepancies were small, and the firm required large amounts of credit and highly leveraged positions in order to achieve an attractive return on capital. ${ }^{10}$ It used collateralized credits from its counterparties in transactions in stocks, bonds and derivative instruments and an uncollateralized credit line from a syndicate of international banks. Estimates of LTCMs leverage in its final pre-reorganization days suggest that the firm had less than $\$ 1$ billion in capital to offset positions in securities worth $\$ 120$ billion and derivatives with a notional value of $\$ 1.3$ trillion. ${ }^{11} \mathrm{As}$

\footnotetext{
${ }^{9}$ Total positions may have exceeded identified positions insofar as hedge funds disguised their trades by, inter alia, booking them through third parties who held their beneficial interest.

${ }^{10} \mathrm{As}$ it grew, the fund also diversified into a variety of related and unrelated relative value (and other) trades.

${ }^{11}$ Wolffe (1998), p.15. IMF (1998) estimates that in the final days of the crisis (on 23 September 1998) LTCMs capital had fallen to just $\$ 600$ million, which still supported on-balance sheet positions in excess of $\$ 100$ billion. To be sure, these figures reflect the crisis-related erosion of the funds capital, which under normal conditions had been in the range of $\$ 5$ billion, together with the reluctance (some would say inability) of its management to liquidate assets at fire-sale prices.
} 
Table 1. Maximum Leverage Before LTCM Crisis, Measure 1

\begin{tabular}{|cccc|}
\hline Choice & Leverage 1 & Number & Share \\
\hline $0 \%$ & 0 & 26 & $12.6 \%$ \\
Under $200 \%$ & 1 & 127 & $61.4 \%$ \\
$200 \%$ & 2 & 20 & $9.7 \%$ \\
$300 \%$ & 3 & 16 & $7.8 \%$ \\
$400 \%$ & 4 & 7 & $3.5 \%$ \\
$500 \%$ & 5 & 5 & $2.0 \%$ \\
$600 \%$ & 6 & 2 & $1.0 \%$ \\
$700 \%$ & 7 & 0 & $0.0 \%$ \\
$800 \%$ & 8 & 1 & $0.5 \%$ \\
Other (>800)\% & 9 & 3 & $1.5 \%$ \\
\hline
\end{tabular}

Number of observations for leverage: 207

Source: see text.

Table 2. Maximum Leverage Before LTCM Crisis, Measure 2

\begin{tabular}{|cccc|}
\hline Choice & Leverage 2 & Number & Share \\
\hline Under 200\% & 0 & 153 & $74.0 \%$ \\
$200 \%$ & 1 & 20 & $9.7 \%$ \\
$300 \%$ & 2 & 16 & $7.8 \%$ \\
$400 \%$ & 3 & 7 & $3.5 \%$ \\
$500 \%$ & 4 & 5 & $2.0 \%$ \\
$600 \%$ & 5 & 2 & $1.0 \%$ \\
$700 \%$ & 6 & 0 & $0.0 \%$ \\
$800 \%$ & 7 & 1 & $0.5 \%$ \\
Other & 8 & 3 & $1.5 \%$ \\
\hline
\end{tabular}

Number of observations for leverage: 207

Source: see text.

the fund approached insolvency, fears arose that the forced liquidation of its positions in U.S. securities markets might add dangerously to the volatility of already volatile financial markets. ${ }^{12}$ These fears in turn led to the New York Fedorchestrated rescue of LTCM and the takeover of the fund by 14 of its leading creditors.

Thus, to a considerable extent the policy debate about the implications of hedge fund operations for systemic stability and market integrity revolves

\footnotetext{
${ }^{12} \mathrm{Had}$ LTCM been forced to file for bankruptcy protection, repurchase and reverse repurchase agreements containing acceleration clauses would have permitted its creditors to immediately sell the underlying securities, since derivatives are exempt from the automatic stay provision of the bankruptcy code (Edwards 1999).
} 
Table 3. Maximum Leverage Following LTCM Crisis

\begin{tabular}{|cccc|}
\hline Choice & Leverage 1 & Number & Fraction \\
\hline None & 0 & 60 & $33.2 \%$ \\
$101-200 \% 200 \%$ & 1 & 101 & $55.8 \%$ \\
$201-300 \%$ & 2 & 11 & $6.1 \%$ \\
$301-400 \%$ & 3 & 0 & $0.0 \%$ \\
$401-500 \%$ & 4 & 5 & $2.8 \%$ \\
$501-600 \%$ & 5 & 1 & $0.6 \%$ \\
$601-700 \%$ & 6 & 0 & $0.0 \%$ \\
$701-800 \%$ & 7 & 1 & $0.6 \%$ \\
$801-900 \%$ & 8 & 2 & $1.1 \%$ \\
Over $901 \%$ & 9 & 0 & $0.0 \%$ \\
\hline
\end{tabular}

Number of observations for leverage: 181

Source: see text.

Table 4. Variable Definitions and Summary Statistics

\begin{tabular}{|c|c|c|c|c|c|c|c|}
\hline \multirow{2}{*}{ Definition } & & \multicolumn{3}{|c|}{ Calendar Year 1998} & \multicolumn{3}{|c|}{ Calendar Year 1999} \\
\hline & & Number & Mean & Std. Dev. & Number & Mean & Std. Dev. \\
\hline Leverage 1 & $\begin{array}{l}\text { Maximum leverage during } 1998 \\
\{(\% \text { leverage/100)- } 1\} \\
\text { No leverage treated as under } \\
200 \%\end{array}$ & & 1.52 & 1.54 & & 0.94 & 1.21 \\
\hline Leverage 2 & $\begin{array}{l}\text { Maximum leverage during } 1998 \\
\{(\% \text { leverage/100)- } 1\} \\
\text { No leverage treated as a separate } \\
\text { choice }\end{array}$ & & 0.65 & 1.45 & & & \\
\hline STYLE 1 & $\begin{array}{l}\text { Equals } 1 \text { if style is arbitrage, neu- } \\
\text { tral, or bond only }\end{array}$ & 61 & & 51 & & & \\
\hline STYLE 2 & $\begin{array}{l}\text { Equals } 1 \text { if style is emerging, } \\
\text { international, macro, Pacific Rim } \\
\text { or Latin America }\end{array}$ & 40 & & & 27 & & \\
\hline ASSETS & Total assets $(\$ \mathrm{~b})$. & & 0.39 & 1.28 & & 0.49 & 1.23 \\
\hline RETURN & Net Performance (\%) & & 13.24 & 42.43 & & 42.98 & 75.88 \\
\hline $\begin{array}{l}\text { HEDGE } \\
\text { RATIO }\end{array}$ & $\begin{array}{l}\text { Hedge Ratio: Max(long, short)- } \\
\text { Min(long, short) (\%) The higher, } \\
\text { the less hedged }\end{array}$ & & 51.46 & 36.11 & & 52.87 & 52.17 \\
\hline $\begin{array}{l}\text { OFFSHR } \\
\text { RATIO }\end{array}$ & $\begin{array}{l}\text { Offshore Ratio: (Offshore assets/ } \\
\text { Total assets) } * 100(\%)\end{array}$ & & 35.74 & 48.95 & & 34.52 & 32.10 \\
\hline DEALER & $\begin{array}{l}\text { Equals } 1 \text { if a manager is Broker } \\
\text { Dealer }\end{array}$ & 25 & & & 23 & & \\
\hline $\mathrm{CPO}$ & $\begin{array}{l}\text { Equals } 1 \text { if a manager is } \\
\text { Commodity Pool Operator }\end{array}$ & 44 & & & 31 & & \\
\hline ADVISOR & $\begin{array}{l}\text { Equals } 1 \text { if a manager is } \\
\text { Registered Investment Advisor }\end{array}$ & 82 & & & 74 & & \\
\hline 3C7 FUND & Equals 1 if a fund is $3 \mathrm{C} 7$ fund & 49 & & & 49 & & \\
\hline
\end{tabular}

Source: see text. 
around their use of leverage. It is to a more systematic analysis of this issue that we now turn.

\section{Data}

Our data are drawn from the annual survey of hedge fund managers conducted by the Henneessee Group, a firm providing advice and analysis to hedge fund managers and investors. We have the returns to two surveys, one conducted in January 1999 and one conducted in January 2000. ${ }^{13}$ The January 1999 survey contains information on 226 management companies responsible for 647 hedge funds, which include all the major investment styles, while the January 2000 survey has responses from 192 management companies covering 634 hedge funds. The respondents to the first survey collectively managed some $\$ 108$ billion of the estimated $\$ 210$ billion invested in the hedge fund industry in 1998 and include, according to the surveyors, the majority of the most important firms. The respondents to the second survey manage $\$ 101$ billion of the estimated $\$ 324$ billion of capital invested in the industry. ${ }^{14}$

Each manager provided the name of his largest fund, described its investment style, and enumerated various of its other attributes. Both surveys included questions about leverage. The January 1999 survey inquired into the maximum amount of leverage utilized in 1998. Since the use of leverage declined after the Russia-LTCM crisis, this maximum almost certainly obtained prior to that event. The question was worded as follows. "What is the maximum amount of leverage your fund(s) utilized in 1998 (stated as a percentage of L.P. capital)?" Boxes were provided for "Under 200\%," 200\%, 300\%, 400\%, 500\%, 600\%, 700\%, 800\%, and "Other $\% . "$

The same question was asked in January 2000, accompanied by more detailed instructions for respondents. "What is the maximum amount of leverage (as defined by the Hennessee Group): portfolio gross exposure (as a \% of L.P. capital) above the first $100 \%$ of L.P. capital in your fund equals your leverage...Include the notional value of derivatives on the gross long and gross short side. Sum the gross

\footnotetext{
${ }^{13}$ Hennessee Group $(1999,2000)$. Otherwise undocumented information in this section is drawn from these publications.

${ }^{14}$ The funds surveyed did not include funds of funds, which would have introduced double counting.

${ }^{15}$ The survey conducted in January 1999 also includes a question about intent -- "Do you plan to use more, less or the same leverage in 1999?" -- with which retrospective descriptions of actual behavior can be compared. According to this survey, 4 per cent of managers anticipated using more leverage, while 10 per cent anticipated using less (the remainder anticipated using the same).
} 
longs with the gross shorts and subtract L.P. capital assets (e.g. 50\% gross long and $50 \%$ gross short would have $0 \%$ leverage..." ${ }^{16}$ In addition, the January 2000 survey breaks the "Under 200\%" category into "none" and "101-200."17

This change in survey methodology between the two years complicates the comparison of the two sets of returns. While the January 1999 survey does not include a separate box to be checked by funds that do not use leverage, a number of managers took the availability of a box labeled "other" to record zero. (Other managers recorded figures in excess of 800 per cent.) This suggests two ways of comparing the surveys. Assuming that all managers whose funds did not utilize leverage in 1998 recorded a zero and that all entries in the "Other" category therefore denote leverage ratios above 800 per cent, the two surveys can be compared directly. ${ }^{18}$ But if some managers whose funds did not use leverage in fact responded by checking the "Under 200" box, it is safer to combine the zero and Under $200 \%$ observations from January 1999, and the zero and 101-200\% observations from January 2000. We report results using the January 1999 survey (of behavior in 1998) under both procedures; it turns out that the results are broadly similar in both cases. The unadjusted data for 1998 we refer to as "Leverage 1." These are shown in Table 1. Note that the results are displayed as intervals rather than point estimates, following the Hennessee Groups practice in its own reports. The alternative, combining the zero and "Under 200\%" responses and denoted "Leverage 2," is shown in Table 2, with the analogous data for 1999 in Table 3. Note that both measures consist of nonnegative integers.

In the empirical model that follows, we will relate maximum use of leverage to

\footnotetext{
${ }^{16}$ The instructions go on, "Exclude boxed positions (long $1000 \mathrm{XYZ}$ shares; short 1000 of XYZ) but include all pair trades or relative value trades in long and gross short total. (Check only one.)"

${ }^{17}$ While the answers are tabulated in the same way in the two surveys (and the meaning of the questions is the same), the 1999 survey asks whether maximum leverage was under $200 \%, 200 \%, 300 \%$ and so forth, while the 2000 survey asks whether it was none, 101-200\%, 201-300\%, etc. Although the wording is slightly different, aside from breaking up the no-and-low leverage category into two, the meaning is the same.

${ }^{18}$ Implicit in this procedure is the further assumption that entries in the "Under 200\%" box indicate leverage ratios of $101 \%$ to $200 \%$.

${ }^{19}$ To questions such as "Are you a broker-dealer" or "Are you a commodity pool operator" we took no response to indicate a no. Where respondents provided the components of the answer to a subsequent question but did not also answer the subsequent question (for example, where they provided total assets and onshore assets but did not supply the share of offshore assets in the total), we constructed the answer to the subsequent question on the basis of the preceding information. We proceeded in similar fashion where respondents provided total and offshore assets but not onshore assets. In a few cases where managers did not provide the value of assets, the return on capital or the hedge ratio, we imputed these on the basis of the average for reporting funds with the same investment style.
} 
each fund's investment style, portfolio characteristics (its size, return on assets, hedge ratio, offshore ratio), and regulatory status. Summary statistics for these characteristic are shown in Table $4 .{ }^{19}$

\section{Estimation}

Our dependent variable, maximum leverage, is an ordered discrete variable. While underlying leverage is continuous, what was obtained through the surveys were responses falling within intervals. From Tables 1-3 it is evident that the smaller the value of this variable, the higher in general is its frequency. Its distribution is skewed to the left; one cannot simply assume that it was generated from the normal distribution. For both reasons we can improve on least squares by using an estimator that accounts for these characteristics.

Since our measure of leverage is assigned to categories indexed by zero and positive integers, its distribution resembles those that are frequently found in count data. ${ }^{20}$ Count data has characteristics similar to those of our dependent variable, namely, discrete observations, a preponderance of zeros, and higher frequencies at lower values. Count data models are used not only for counts that arise from direct observation of a point process but also for those that arise from the ordinalization of continuous latent data, for instance individual or country credit ratings. That is to say, they are used with data like those considered here.

A standard model for count data is Poisson regression, which is derived from the Poisson distribution by allowing the intensity parameter $\mu$ to depend on covariates. If this dependence is parametrically exact and involves exogenous covariates but no other source of stochastic variation, we obtain the standard Poisson regression. This assumes that $y_{i}$, given the vector of regressors $\boldsymbol{X}_{i}$, is independently Poisson distributed with density

$$
f\left(y_{i} \mid X_{i}\right)=\frac{e^{-\mu_{i}} \mu_{i}^{y_{i}}}{y_{i} !}, y_{i}=0,1,2, \ldots
$$

and mean parameter

$$
\mu=\exp \left(X_{i}^{\prime} \beta\right)
$$

where $\beta$ is a parameter vector. This implies that the conditional mean and

\footnotetext{
${ }^{20}$ Other applications where count-data models have been used include doctors visits, airline accidents, patent registrations, and bank failures. See Cameron and Trivedi (1998).
} 
conditional variance are given by:

$$
E\left(y_{i} \mid X_{i}\right)=V\left[y_{i} \mid X_{i}\right]=\exp \left(X_{i}^{\prime} \beta\right)
$$

The model therefore assumes equi-dispersion, that is, the equality of conditional mean and conditional variance. Maximum likelihood can then be used to estimate the parameter vector $\beta$.

The assumed equality of the conditional mean and variance functions is a limitation of the Poisson model. In practice, count data frequently display overdispersion, which means that the conditional variance is larger than the conditional mean. Our measure of leverage in fact has a mean larger than its variance. Several alternatives have been suggested to accommodate this fact, the most common of which is the negative binomial model. This assumes that the data is Poisson but that there is an unobserved individual heterogeneity reflecting the fact that the true mean is not perfectly observed.

$$
\mu=\exp \left(X_{i}^{\prime} \beta+\varepsilon_{i}\right)
$$

The unobserved heterogeneity term $v_{i}=\exp \left(\varepsilon_{i}\right)$ could reflect a specification error such as unobserved omitted exogenous variables. For mathematical convenience, $v_{i}$ is assumed to have a gamma distribution $g\left[v_{i}\right]$ with $E\left[v_{i}\right]=1$, and $V\left[v_{i}\right]=\alpha$. Then the unconditional (or marginal) distribution of $y_{i}, h\left(y_{i} \mid \boldsymbol{X}_{i}\right)$, is the expected value

\begin{tabular}{|c|c|c|c|c|c|c|c|c|c|}
\hline & \multicolumn{4}{|c|}{ Leverage 1} & \multicolumn{5}{|c|}{ Leverage 2} \\
\hline & $\begin{array}{c}\text { Ordered } \\
\text { probit }\end{array}$ & Possion & & B2 & $\begin{array}{c}\text { Ordered } \\
\text { probit }\end{array}$ & Poss & sion & & JB2 \\
\hline Constant & 0.676 & -0.086 & 0.086 & & -1.363 & $-\mathbf{1 . 9 7 7}$ & & -2.090 & \\
\hline Style 1 & 1.160 & $0.767 \quad 1.166$ & 0.767 & 1.166 & 1.255 & 2.032 & 1.321 & 2.059 & 1.338 \\
\hline Style 2 & 0.291 & $\begin{array}{ll}0.372 & 0.519\end{array}$ & 0.372 & 0. & 0.617 & 1.493 & 0.970 & 1.364 & 0.887 \\
\hline Ass & 0.139 & 0.0630 .096 & 0.063 & 0.1 & 0.120 & 0.091 & 0.059 & 0.109 & 0.071 \\
\hline & 0.001 & $-0.001-0.001$ & 0.001 & -0 & - & -0.006 & -0 & -0.004 & -0.003 \\
\hline $\mathrm{He}$ & 0.001 & $-0.001-0.001$ & 0.001 & -0 & -0.001 & -0.002 & -0 & -0.000 & -0.000 \\
\hline Off & 0.000 & $0.000 \quad 0.000$ & 0.000 & 0.000 & -0.001 & -0.000 & -0.000 & -0.000 & -0.000 \\
\hline Deal & 0.815 & $\begin{array}{ll}0.595 & 0.904\end{array}$ & 0.595 & 0.9 & 0.888 & 1.125 & 0.731 & 1.008 & 0.655 \\
\hline $\mathrm{CPO}$ & 683 & $\begin{array}{ll}0.516 & 0.784\end{array}$ & 0.516 & & 0.598 & 0.979 & 0.636 & 1.013 & 0.658 \\
\hline Ad & -0.070 & $-0.150-0.228$ & -0.150 & -0.228 & -0.146 & -0.524 & -0.341 & -0.323 & -0.210 \\
\hline $3 C 7$ fund & -0.149 & $-0.173-0.263$ & -0.173 & -2.263 & -0.085 & -0.375 & -0.244 & -0.209 & -0.136 \\
\hline$\alpha$ & & & 0.000 & & & & & 1.106 & \\
\hline
\end{tabular}

Table 5. Deteminants of Leverage Before LTCM

Notes: Values in bold are significant at the 5\% level.

$\alpha$ is a determinant of conditional variance. 
(over $v_{i}$ ) of the distribution of $y_{i}$ conditioned on $\mathbf{X}_{\mathrm{i}}$ and $v_{i}, f\left(y_{i} \mid \boldsymbol{X}_{i}, v_{i}\right)$, which is the Poisson distribution. By implication:

$$
h\left(y_{i} \mid X_{i}\right)=\int f\left(y_{i} \mid X_{i}, v_{i}\right) g\left(v_{i}\right) d v_{i}
$$

Finally, we can obtain a form of the negative binomial distribution:

$$
h\left(y_{i} \mid X_{i}\right)=\frac{\Gamma\left(\alpha^{-1}+y\right)}{\Gamma\left(\alpha^{-1}\right) \Gamma(y+1)}\left(\frac{\alpha^{-1}}{\alpha^{-1}+\mu}\right)^{a^{-1}}\left(\frac{\mu}{\mu+\alpha^{-1}}\right)^{y}
$$

where $\Gamma(\cdot)$ is the gamma function. The distribution $h(\cdot)$ has conditional mean $\mu=$ $\exp \left(x_{i} \beta\right)$ and conditional variance $\mu+\alpha \mu^{2}$. The model based on this distribution is commonly referred to as "NB2." Now the variance is no longer equal to the mean. $\alpha$, which is a determinant the variance, is to be estimated, so that model can handle the under- or over-dispersion problem.

An alternative is to use the ordered probit model. Ordered discrete-choice models, of which this is an example, treat the data as generated by a continuous unobserved latent variable, which on crossing a threshold leads to an increase of one in the observed variable. The ordered probit model introduces a latent (unobserved) random variable

$$
y_{i}^{*}=X_{i}^{\prime} \beta+\varepsilon_{i}
$$

where $\varepsilon_{i}$ is $\mathrm{N}[0,1]$. The observed discrete variable $y_{i}$ is generated from the unobserved $y_{i}^{*}$ as:

$$
\begin{gathered}
y_{i}=j \text { if } \alpha_{j}<y_{i}^{*} \leq \alpha_{j+1}, j=0, \ldots, m \\
P_{i j}=\operatorname{Pr}\left[y_{i}=j\right] \\
=\operatorname{Pr}\left[\alpha_{j}<y_{i}^{*} \leq \alpha_{j+1}\right] \\
=\operatorname{Pr}\left[\left(\alpha_{j}-X_{i}^{\prime} \beta\right)<\varepsilon_{i} \leq \alpha_{j+1}-X_{i}^{\prime} \beta\right] \\
\Phi\left(\alpha_{j+1}-X_{i}^{\prime} \beta\right)-\Phi\left(\alpha_{j}-X_{i}^{\prime} \beta\right)
\end{gathered}
$$

where $\Phi(\cdot)$ is the standard normal cdf, and $\alpha_{0}=-\infty, \alpha_{m+1}=\infty$. Typically $\beta$ and $\alpha_{1}$ $, \ldots, \alpha_{m}$ are estimated by maximum likelihood. In our case, the dependent variable is derived from a laten continuous variable. This suggests using an ordered probit model.

\section{Results}

Table 5 reports the results for the first (pre-LTCM) survey using our two 
Table 6. Determinants of Leverage After LTCM

\begin{tabular}{|c|c|c|c|c|c|c|c|c|c|c|}
\hline & \multicolumn{5}{|c|}{ Leverage 1} & \multicolumn{5}{|c|}{ Leverage 2} \\
\hline & $\begin{array}{c}\text { Ordered } \\
\text { probit }\end{array}$ & Poi & sson & \multicolumn{2}{|c|}{ NB2 } & $\begin{array}{c}\text { Ordered } \\
\text { probit }\end{array}$ & \multicolumn{2}{|c|}{ Possion } & \multicolumn{2}{|c|}{ NB2 } \\
\hline Constant & 0.300 & -0.040 & & -0.058 & & -1.935 & -3.153 & & -3.327 & \\
\hline Style 1 & 0.475 & 0.614 & 0.577 & 0.610 & 0.573 & 1.662 & 3.832 & 1.073 & 3.815 & 1.068 \\
\hline Style 2 & 0.561 & 0.577 & 0.542 & 0.574 & 514 & 1.334 & 3.637 & 1.018 & 3.308 & 0.926 \\
\hline Assets & -0.069 & -0.104 & -0.098 & -0.097 & -0.091 & -0.287 & -0.865 & -0.242 & -0.670 & -0.188 \\
\hline Retu & -0.002 & -0.001 & -0.0 & -0.001 & -0.001 & 0.001 & 0.004 & 0.001 & 0.001 & 0.000 \\
\hline Hedg & -0.000 & -0.003 & -0.003 & -0.002 & -0.002 & -0.005 & -0.015 & -0.004 & -0.012 & -0.003 \\
\hline Offsh & -0.004 & -0.001 & -0.001 & 0.001 & 0.001 & -0.001 & -0.006 & -0.002 & -0.005 & -0.001 \\
\hline Deal & 0.314 & 0.195 & 0.183 & 0.188 & 0.177 & 0.560 & 0.628 & 0.176 & 0.541 & 0.151 \\
\hline $\mathrm{CPO}$ & 0.135 & -0.097 & -0.091 & -0.080 & -0.075 & -0.015 & -0.949 & -0.267 & -0.306 & -0.086 \\
\hline Advi & -0.033 & -0.197 & -0.185 & -0.181 & -0.170 & -0.168 & -0.744 & -0.208 & -0.521 & -0.146 \\
\hline 3C7fund & -0.324 & -0.407 & -0.383 & -0.396 & -0.372 & -0.420 & -1.330 & -0.372 & -1.112 & -0.311 \\
\hline$\alpha$ & & & & 0.015 & & & & & 2.669 & \\
\hline
\end{tabular}

Notes: Values in bold are significant at the $5 \%$ level.

$\alpha$ is a determinant of conditional variance.

Table 7. Likelihood Ratio Tests: P-values

\begin{tabular}{|lccc|ccc|}
\hline Null hypothesis $\begin{array}{l}\text { Leverage 1 } \\
\text { (no change in the following } \\
\text { coefficients) }\end{array}$ & \multicolumn{3}{c|}{ Leverage 2 } \\
\cline { 2 - 7 } & Ord. Probit & Poisson & NB2 & Ord. Probit & Poisson & NB2 \\
\hline All & 0.000 & 0.001 & 0.002 & 0.009 & 0.000 & 0.005 \\
Investment Style & 0.061 & 0.434 & 0.439 & 0.443 & 0.080 & 0.159 \\
Management & 0.159 & 0.432 & 0.454 & 0.419 & 0.007 & 0.189 \\
Regulatory Characteristics & 0.332 & 0.052 & 0.069 & 0.507 & 0.001 & 0.188 \\
\hline
\end{tabular}

Source: see text.

measures of leverage. In the count data model, the coeffients do not have the same meaning as in the linear regression model. Consider the expotentioal condition mean of the Poisson model

$$
E(y \mid X)=\exp \left(X^{\prime} \beta\right)
$$

Let the scalar $x_{i}$ denote the $j^{\text {th }}$ regressor. Differentiating:

$$
\begin{gathered}
\partial E[y \mid X] / \partial x_{j}=\beta_{j} \exp \left(X^{\prime} \beta\right) \\
=\beta_{j} E[y \mid X] \\
=\beta_{j} \bar{y}
\end{gathered}
$$


Thus, a one unit change in the $j^{\text {th }}$ regressor increases the expectation of $y$ by approximately $\beta_{j}$ times mean of $y$. Therefore, in the Poisson model, $\beta_{j} \bar{y}$ has the same meaning as $\beta_{j}$ in the linear regression model.

Neither the signs nor the magnitudes of the coefficients are particularly sensitive to how the equation is estimated or leverage is measured, although levels of statisical significance vary. We find that arbitrage, market-neutral and fixedincome funds ("Style 1 funds"), which are regarded by managers and shareholders as low risk, use high levels of leverage relative to growth, opportunistic, distressed, value, event, financial, and short funds, which are the omitted alternative. According to the Poisson regression using Leverage 1, a coefficient of 0.77 , together with a mean of the dependent variable of 1.52, implies that Style 1 funds use 117 per cent more leverage than other funds. There is also some evidence pointing in this direction for emerging market, Latin American, Pacific Rim, international and macro funds ("Style 2 funds"), but the coefficient for this category is smaller and only differs significantly from zero in some of the equations. The point estimates suggest that such funds use about 52 per cent more leverage $(0.37 * 1.52)$ than those in the omitted-alternative category. Even after controlling for other characteristics, then, we find that leverage varies by investment style.

There are strong indications that larger funds (measured by the value of assets) use more leverage and somewhat weaker evidence that funds that are less hedged (measured by the difference between maximum long and short positions in the calendar year, in absolute value terms) and that have more offshore assets use less leverage.

We also find that fund companies that register with the Securities and Exchange Commission as commodity pool operators and broker-dealers are significantly more leveraged than other hedge funds. There is also some indication that Registered Investment Advisors (RIAs) and 3C7 funds use less leverage, though it is statistically less robust. Recall that broker-dealers and RIAs are subject to registration, recordkeeping, and reporting requirements under the Commodity Exchange Act. It has been argued that greater disclosure to counterparties, regulators and the public will discourage excessive use of leverage, since risky practices are less likely to take place in the light of day. This is not what we find. It could be that other characteristics of these funds offset any tendency for more stringent disclosure and reporting requirements to reduce the use of leverage; this is most obviously true for broker-dealers, who play important roles as market 
makers and liquidity providers and frequently have boxed positions which reduce economic risk. However, the absence of evidence that other funds required to report additional information to regulators use less leverage (whether it suggests greater use of leverage as in the case of CPOs, or no difference as in the case of Registered Investment Advisors) casts doubt on this presumption.

The results for the second survey (after LTCM) in Table 7 are broadly similar, not withstanding some differences. The general direction of these changes can be anticipated from the fall in the mean value of the dependent variable (Leverage 1), which is 1.52 in the first survey and 0.94 in the second. ${ }^{21}$ It is not the case, however, that these changes are evenly distributed. After LTCM, there is a tendency for larger hedge funds to use less leverage, which is the opposite of the pattern found for the previous period. This is consistent with press reports of larger hedge funds turning to less risky strategies following the crisis. Any tendency for broker-dealers and Registered Investment Advisors to use more leverage than other funds is now weaker. In addition, the constant term and the dummy variable for investment style 1 is smaller than in the earlier survey (compare Table 6). The smaller constant term indicates a tendency for all hedge funds, regardless of investment style, to have reduced their leverage after the LTCM crisis. The smaller coefficient on Style 1 indicates in addition a tendency for funds with investment styles generally associated with high leverage to reduce their use of credit disproportionately following the crisis.

We can test for structural change between the two years with a likelihood ratio test. If $L_{1}$ is the value of the logarithm of the likelihood of the unconstrained model and $L_{0}$ is the value when the constraints are imposed, then the statistic for the likelihood ratio test is $2\left(L_{1}-L_{0}\right){ }^{22}$ The likelihood ratio statistic is distributed

Table 8. Decomposition of Sources of Decline in Average Leverage

\begin{tabular}{|lcccc|}
\hline & \multicolumn{2}{c}{ Leverage 1 } & \multicolumn{2}{c|}{ Leverage 2 } \\
\hline $\mathrm{E}\left(\mathrm{y}^{1}\right)-\mathrm{E}\left(\mathrm{y}^{2}\right)$ & 0.577 & $100 \%$ & 0.371 & $100 \%$ \\
$\mathrm{E}\left(\hat{y}^{11} 11\right)-\mathrm{E}\left(\hat{y}^{21}\right)$ & 0.012 & $2.0 \%$ & $-0.040-$ & $-10.8 \%$ \\
$\mathrm{E}\left(\hat{y}^{21}\right)-\mathrm{E}\left(\hat{y}^{22}\right)$ & 0.326 & $56.5 \%$ & 0.260 & $70.0 \%$ \\
$\mathrm{E}\left(e^{1}\right)-\mathrm{E}\left(e^{2}\right)$ & 0.239 & $41.5 \%$ & 0.152 & $40.9 \%$ \\
\hline
\end{tabular}

Source: see text.

\footnotetext{
${ }^{21}$ Similarly, the share of funds reporting that they had asset/capital ratios of 200 per cent or less rose from 74 per cent to 89 per cent between surveys.

${ }^{22}$ It is always positive (or zero) since the likelihood of the unconstrained model is at least as high as that of the constrained model.
} 
asymptotically as a chi-squared variable with degrees of freedom equal to the number of constraints.

We test four null hypotheses. First, all coefficients (including the constant) are unchanged. Second, the effects of investment style (Style1, Style2) are unchanged. Third, the coefficients on the management characteristics (assets, returns, hedge ratio, offshore ratio) are unchanged. Fourth, the coefficients on regulatory status (dealer, cpo, advisor, 3C7 fund) are unchanged.

The results are shown in Table 7 . The null that all coefficients remain unchanged is decisively rejected (at the $1 \%$ confidence level). Clearly, there were important structural changes in leverage behavior. Tests of the other hypotheses are sensitive to how leverage is measured and the equation is estimated. Four of the six test statistics suggest that regulatory status mattered for the decline in leverage, suggesting that more intense regulatory scrutiny may have been part of this process.

Finally, we can decompose the decline in leverage into that part due to changes in behavior and that part due changes in the coefficients (into the parts attributable to changes in the coefficients and the value of the independent variables). Using the results obtained from estimating the ordered probit model, we can distinguish the sources of the decline in the sample mean, following the method of Oxaca. Let:

\section{$y^{1}$ : Leverage in 1998}

$y^{2}$ : Leverage in 1999 ,

where the superscripts 1 and 2 denote year of 1998 and of 1999 respectively. $y^{1}$ and $y^{2}$ can be expressed as:

$$
\begin{aligned}
& y^{1}=\hat{y}^{11}+e^{1} \\
& y^{2}=\hat{y}^{22}+e^{2}
\end{aligned}
$$

where $\hat{y}^{11}$ and $\hat{y}^{22}$ denote predicted leverage in 1998 and 1999, and the $e$ 's are error terms.

$$
\begin{aligned}
& \hat{y}^{11}=F\left(X^{1} \hat{\beta}^{1}, \hat{\alpha}^{1}\right) \\
& \hat{y}^{22}=F\left(X^{2} \hat{\beta}^{2}, \hat{\alpha}^{2}\right)
\end{aligned}
$$

where $F(\cdot)$ is the function of ordered probit model, and $X$ and $\ddot{\beta}$ are the determinant matrix and estimator vectors of coefficient and threshold point respectively. The change in the sample mean of leverage can be expressed as: 


$$
E\left(y^{1}\right)-E\left(y^{2}\right)=\left\{E\left(\hat{y}^{11}\right)-E\left(\hat{y}^{22}\right)\right\}+\left\{E\left(e^{1}\right)-E\left(e^{2}\right)\right\}
$$

To apply the Oxaca decomposition, we introduce the term $\mathrm{E}\left(\hat{y}^{21}\right)$, where

$$
\hat{y}^{21}=F\left(X^{2} ; \hat{\beta}^{1}, \hat{a}^{1}\right)
$$

$\hat{y}^{21}$ thus denotes the leverage predicted by the values of the independent variables in 1999, assuming that the coefficients remained unchanged at their 1998 levels. Adding and subtracting $\mathrm{E}\left(\hat{y}^{21}\right)$ and rearranging yields:

$$
E\left(y^{1}\right)-E\left(y^{2}\right)=\left\{E\left(\hat{y}^{11}\right)-E\left(\hat{y}^{21}\right)\right\}+\left\{E\left(\hat{y}^{21}\right)-E\left(\hat{y}^{22}\right)\right\}+\left\{E\left(e^{1}\right)-E\left(e^{2}\right)\right\}
$$

The first term on the right-hand side is the contribution to the decline in leverage of the change in its determinants (the $X^{\prime} \mathrm{s}$ ). The second term is the contribution of the change in the coefficients (the $\alpha$ and $\beta$ ). The last term is the decline due to the unobservable $(e)$.

Table 8 shows that the change in the independent variables accounts for only two per cent of the decline in the sample mean (of Leverage 1), while the change in the coefficients accounts for 56.5 per cent of the decline. The remaining 41.5 per cent is explained by the unobservable. For Leverage 2, the change in the coefficients accounts for 70.0 percent of the decline in leverage, while the change in the determinants works in the other direction. Both measures thus suggest that the decline in leverage is a result of the change in the behavior and practices determining its use rather than unchanging behavior but changing conditions.

\section{Conclusions}

In this paper we have analyzed the determinants of hedge fund's use of leverage in 1998 and 1999 -- roughly speaking, before and after the LTCM crisis. Our analysis has confirmed the widely noted tendency for hedge funds to reduce their use of leverage and credit following the Russia-LTCM affair. In addition, we have shed light on the determinants of the use of leverage by different kinds of funds and pinpointed the sources of its post-LTCM decline. We have shown that use of leverage varies importantly by investment style, regulatory status, and other individual fund attributes. It is those funds whose investment styles, regulatory status and other attributes were associated with the greatest dependence on leverage in 1998 that reduced their use of leverage most dramatically in 1999. The reduction in leverage reflected not changes in determinants of leverage (the mix of 
investment styles, fund sizes, and regulatory status) as much as changes in behavior, given those characteristics. It is clear that fund managers and counterparties better recognized the risky nature of highly-leveraged positions as a result of the collapse of LTCM and adjusted their behavior accordingly. Whether that change proves permanent or temporary only further studies will tell.

\section{Acknowledgement}

The authors affiliations are at the University of California, Berkeley and Presidential Commission on Policy Planning, Government of Korea, respectively. This paper was begun while the second author was visiting UC Berkeley. We are grateful to Lee Hennessee of the Hennessee Group Llc for providing data.

Date accepted: September 2001

\section{References}

Basle Committee on Banking Supervision (1999), Sound Practices for Banks' Interactions with Highly-Leveraged Institutions, Basle: BIS.

Basle Committee on Banking Supervision (2000), Banks' Interactions with HighlyLeveraged Institutions: Implementation of the Basle Committee's Sound Practices Paper, Basle: BIS.

Cameron, A. Colin and Pravin K. Trivedi (1998), Regression Analysis of Court Data, Cambridge: Cambridge University Press.

Chadha, Bankim and Anne Jansen (1998), “The Hedge Fund Industry: Structure, Size and Performance,"' in Barry Eichengreen and Donald Mathieson et al., Hedge Funds and Financial Market Dynamics, Occasional Paper no. 166, Washington, D.C.: International Monetary Fund (May).

De Brouwer, Gordon (2001), Hedge Funds in Emerging Markets, Cambridge: Cambridge University Press.

Edwards, Franklin (1999), "Hedge Funds and the Collapse of Long-Term Capital Management," Journal of Economic Perspectives 13, pp.189-210.

Eichengreen, Barry and Donald Mathieson et al. (1998), Hedge Funds and Financial

Market Dynamics, Occasional Paper no. 166, Washington, D.C.: International Monetary Fund (May).

Financial Stability Forum, Market Dynamics Study Group (2000), Report, Annex E3 to Report of the Working Group on Highly-Leveraged Institutions, Basle: Financial Stability Forum.

Hale, David (2001), "Have Hedge Funds Become an Agent of Monetary Policy?" 
unpublished manuscript, Zurich Financial Services (13 June).

Hennessee Group (1999), Annual Hennessee Hedge Fund Manager Survey, New York: Hennessee Group (January).

Hennessee Group (2000), Annual Hennessee Hedge Fund Manager Survey, New York: Hennessee Group (January).

International Monetary Fund (1998), Interim World Economic Outlook and International Capital Markets Report, Washington, D.C.: IMF (September).

Lowenstein, Roger (2000), When Genius Failed: The Rise and Fall of Long-Term Capital Management, New York: Random House.

Metzger, Leon, "Testimony by Paloma Partners Company Llc, Leon M. Metzger, President," Subcommittee on Capital Markets, Securities and Government-Sponsored Enterprises of the Committee on Banking and Financial Services, U.S. House of Representatives (3 March), http://www.house.gov/banking/3399metz.htm.

Rankin, Bob (1999), "The Impact of Hedge Funds on Financial Markets: Lessons from the Experience of Australia," in Luke Gower and David Gruen (eds), Capital Flows and the International Financial System, Sydney: Reserve Bank of Australia, pp.151163.

U.S. President's Working Group on Financial Markets (1999), "Hedge Funds, Leverage, and the Lessons of Long-Term Capital Management," Report of the Presidents Working Group on Financial Markets, Washington, D.C.: GPO.

U.S. Congress, House of Representatives (1994), Risks that Hedge Funds Pose to the Banking System, Committee on Banking, Finance and Urban Affairs, 103rd Congress, 2nd Session.

Wolffe, Richard (1998), "Washington Plans Powers to Cut Hedge Fund Risks," Financial Times (17 September, p.A15).

Yago, Glenn, Lalita Ramesh and Noah E. Hochman (1998), "Hedge Funds and Systemic Risk Demystified," Milken Institute Policy Brief (December).

Yam, Joseph C.K. (1999), "Capital Flows, Hedge Funds and Market Failure: A Hong Kong Perspective," in David Gruen and Luke Gower (eds), Capital Flows and the International Financial System, Sydney: Reserve Bank of Australia, pp.164-179. 